\title{
EFEK KATERING DIVIDEN
}

\author{
Winston Pontoh \\ (Email : winston_pontoh@yahoo.com)
}

\begin{abstract}
Dividend still considered as the main factor affecting the stock price in capital market, because by dividend, the investors will attract for buying or selling their stocks. And by these behaviors, the stock price will fluctuate in capital market. In the other side, managers also believe that, the stock price will increase if they are announcing dividend payment. This phenomenon make the managers tend to behave paying dividends in terms if their stock price valued higher by investors in capital market. In other words, the managers will cater the investors, if in first condition, the investors valuing higher their stock price.

This study is using 103 entities listed in Indonesia Stock Exchange in period of 2009 until 2013, and conducting Analysis of Covariate Model (ANCOVA) for hypothesis testing. The results of analysis is show that stock price have significant effect to dividend, while entities with code $\mathrm{DP}_{5}$ are the most entities who significant effect to dividend.
\end{abstract}

Keywords : signaling, catering theory, stock price, dividend.

\section{Pendahuluan}

Dividen merupakan harapan setiap investor yang dianggap sebagai tingkat keuntungan atau pengembalian dari investasi sahamnya. Dividen masih dianggap sebagai faktor utama dalam memicu pergerakan harga saham dalam pasar modal (Abrutyn dan Turner, 1990; Yoon dan Starks, 1995; Zaman, 2011; Srinivasan, 2012; Zakaria, Muhammad dan Zulkifli, 2012; Gordon, 1959; Shiller, 1981). Dan dengan adanya kebijakan dividen, maka para investor akan bereaksi untuk melakukan penjualan atau pembelian saham dalam pasar modal, yang akan mempengaruhi pergerakan harga pasar saham itu sendiri (Black, 1996).

Akan tetapi, di lain pihak, para entitas yang membagikan dividen juga mempercayai bahwa, pada saat mereka membagikan dividen kepada para pemegang saham mereka, maka harga pasar atas saham mereka dalam pasar modal juga akan mengalami kenaikan. Sehingga hal ini menyebabkan para entitas pembayar dividen akan membagikan dividen pada saat harga pasar saham mereka berada pada penilaian yang tinggi (Easterbrook, 1984; Baker dan Wurgler, 2004a, 2004b).

Penelitian ini bertujuan untuk memberikan bukti empiris tentang efek katering atau sering disebut catering theory yaitu dampak dari harga pasar saham terhadap jumlah pembayaran dividen yang akan dikaitkan dengan signaling theory.

\section{Tinjauan Pustaka}

Miller dan Rock (1985) menyatakan bahwa, pada saat kenaikan harga pasar merefleksikan laba dan peluang laba masa depan dari entitas, maka adanya pengumuman pembagian dividen mengisyaratkan informasi atas prospek laba masa depan entitas, walaupun isi dari informasi tersebut masih belum terlalu jelas.

Menurut Baker dan Wurgler (2004a, 2004b), dalam teori katering, terdapat 3 (tiga) hal mendasar, yaitu : pertama, alasan psikologis atau institusional, dimana beberapa investor yang tidak memiliki informasi atas entitas meminta entitas untuk membagikan dividennya secara tunai; kedua, adanya keterbatasan informasi menyebabkan permintaan ini mempengaruhi harga pasar saham dari entitas yang membagikan atau tidak membagikan dividen; ketiga, manajer entitas secara rasional akan memenuhi permintaan investor atas dividen dengan syarat para investor harus dapat menilai secara lebih nilai pasar saham entitas dalam pasar modal. Baker dan Wurgler (2004a) menyatakan bahwa, intisari dari teori 
katering adalah para manajer entitas akan memenuhi permintaan dividen dari investor, akan tetapi keputusannya adalah terbatas pada pembayaran dan bukan pada jumlah dividen yang akan dibayarkan. Sehingga implikasi dari teori ini adalah dividen memiliki relevansi yang cukup tinggi terhadap harga pasar saham, akan tetapi berada pada arah yang berbeda dan waktu yang berbeda.

\section{III.Hipotesis dan Model}

Hasil penelitian dari Black dan Scholes (1974), John dan Williams (1985), dan Li dan Lie (2006) menunjukkan bahwa adanya pengaruh harga pasar saham terhadap pembagian dividen dari entitas kepada pemegang sahamnya.

\section{$H_{a 1}:$ Harga pasar saham berpengaruh terhadap dividen.}

Berdasarkan hipotesis yang diberikan, maka model dari penelitian ini dapat dirumuskan sebagai berikut :

$$
\text { Dividen }=\alpha+\beta \text { Harga Saham }+\beta \mathrm{DP}_{0}+\beta \mathrm{DP}_{1}+\beta \mathrm{DP}_{2}+\beta \mathrm{DP}_{3}+\beta \mathrm{DP}_{4}+\beta \mathrm{DP}_{5}
$$

\section{Metode Penelitian}

\subsection{Data}

Data dalam penelitian ini mengambil sampel 103 entitas bisnis yang terdaftar dalam Bursa Efek Indonesia pada periode tahun 2009 sampai dengan tahun 2013. Data observasi dalam penelitian ini secara keseluruhan adalah berjumlah 515 data observasi.

\subsection{Variabel dan Pengukuran Variabel}

Variabel-variabel yang digunakan dalam penelitian ini adalah sebagai berikut :

1. Dividen.

Dalam penelitian ini, dividen digunakan sebagai variabel dependen yang diukur dengan menggunakan satuan Rupiah.

2. Harga saham.

Dalam penelitian ini, harga saham merupakan harga pasar penutupan setelah disesuaikan dengan adanya kebijakan entitas, dan diukur dengan menggunakan satuan Rupiah.

3. Entitas pembayar dividen.

Dalam penelitian ini, entitas pembayar dividen dikontrol berdasarkan kategori jumlah tahun pembayaran dividen dan diukur dengan dummy. Kode $\mathrm{DP}_{0}$ artinya tidak terdapat satu tahun pun dividen yang dibayarkan oleh entitas, sedangkan kode $\mathrm{DP}_{1}$ artinya bahwa entitas hanya membayar dividen sebanyak 1 kali selama 5 tahun.

\subsection{Metode Analisis}

Dalam penelitian ini, metode analisis yang akan digunakan untuk pengujian hipotesis adalah menggunakan uji Analysis of Covariate Model (ANCOVA).

\section{Hasil Analisis dan Pembahasan}

\subsection{Hasil Analisis}

Berdasarkan statistik deskriptif menunjukkan hasil sebagai berikut : 
Tabel 1. Statistik Deskriptif

\begin{tabular}{lrrr}
\hline Pembayar Dividen & Jumlah Entitas & Rata-Rata Harga Saham & Rata-Rata Dividen \\
\hline $\mathrm{DP}_{0}$ & 28 & 997.44 & 0 \\
$\mathrm{DP}_{1}$ & 9 & 364.18 & 2.64 \\
$\mathrm{DP}_{2}$ & 9 & $2,412.36$ & 48.07 \\
$\mathrm{DP}_{3}$ & 6 & $2,707.80$ & 45.53 \\
$\mathrm{DP}_{4}$ & 16 & $9,623.24$ & 186.36 \\
$\mathrm{DP}_{5}$ & 35 & $7,534.89$ & 262.39 \\
\hline
\end{tabular}

Hasil statistik deskriptif (lihat Tabel 1) menunjukkan terdapat kemiripan pada setiap entitas dengan kode $\mathrm{DP}_{1}, \mathrm{DP}_{2}$ dan $\mathrm{DP}_{5}$ yang memiliki nilai dividen lebih tinggi akan tetapi memiliki harga pasar saham yang lebih rendah, dibandingkan dengan entitas dengan kode $\mathrm{DP}_{0}, \mathrm{DP}_{3}$, dan $\mathrm{DP}_{4}$ yang memiliki nilai dividen lebih rendah akan tetapi memiliki harga pasar saham yang lebih tinggi.

Fenomena ini akan dianalisis lebih lanjut dengan menggunakan analisis ANCOVA seperti yang ditunjukkan berikut ini :

Tabel 2. Analisis ANCOVA

\begin{tabular}{lrr}
\hline \multirow{2}{*}{ Variabel Independen } & \multicolumn{2}{c}{ Variabel Dependen : Dividen } \\
\cline { 2 - 4 } & \multicolumn{2}{c}{ Koefisien } \\
\hline Konstan & -11.509 & 0.000 \\
Harga Saham & 0.012 & 0.888 \\
$\mathrm{DP}_{1}$ & 9.943 & 0.652 \\
$\mathrm{DP}_{2}$ & 31.745 & 0.755 \\
$\mathrm{DP}_{3}$ & 25.794 & 0.138 \\
$\mathrm{DP}_{4}$ & 86.829 & 0.000 \\
$\mathrm{DP}_{5}$ & 186.957 & \\
\hline
\end{tabular}

Pembanding $\mathrm{DP}_{0}$

*signifikan pada tingkat $5 \%$

Berdasarkan hasil analisis ANCOVA (lihat Tabel 2), maka dapat terlihat bahwa, harga pasar saham memiliki pengaruh signifikan terhadap pembagian dividen oleh entitas. Selain itu, berdasarkan kategori pembayar dividen, entitas dengan kode $\mathrm{DP}_{5}$ memiliki pengaruh signifikan terhadap pembagian dividen.

\subsection{Pembahasan}

Hasil analisis dalam penelitian ini mendukung pernyataan dari Baker dan Wurgler (2004a) yang berarti efek katering atau Catering Theory terjadi dalam pasar modal di Indonesia. Sehingga, efek sinyal bukan hanya berasal dari sisi entitas akan tetapi dapat juga berasal dari investor. Hasil penelitian ini juga mendukung hasil penelitian dari Black dan Scholes (1974), John dan Williams (1985), dan Li dan Lie (2006).

Khusus untuk entitas dengan kode $\mathrm{DP}_{5}$, walaupun dalam hasil statistik deskriptif menunjukkan memiliki harga pasar saham yang lebih rendah dibandingkan dengan entitas kode $\mathrm{DP}_{4}$, akan tetapi berdasarkan hasil analisis ANCOVA, entitas kode $\mathrm{DP}_{5}$ adalah merupakan entitas yang paling merespon setiap kenaikan harga pasar saham yang merupakan akibat dari respon psikologis investor. Dalam hal ini, dapat dikatakan bahwa, saham entitas dengan kode $\mathrm{DP}_{5}$ dapat memberikan rasa aman bagi para investornya, sehingga kemungkinan terbesar penjelasan bagi saham entitas kode $\mathrm{DP}_{4}$ adalah harapan investor akan adanya keuntungan modal (capital gain). 


\section{Kesimpulan}

Secara empiris, mendukung efek sinyal, efek katering dapat berlaku dalam pasar modal di Indonesia, walaupun harga pasar saham dari entitas pembayar dividen tidak secara mutlak memiliki harga pasar saham tertinggi sebagai hasil dari penilaian para investor.

\section{DAFTAR PUSTAKA}

Abrutyn, S., dan Turner, R.W. (1990). Taxes \& Firm's Dividend Policies : Survey Results. National Tax Journal, 43(4), 491-96.

Baker, M., dan Wurgler, J. (2004a). A Catering Theory of Dividends. The Journal of Finance, 59(30), 1125-1165.

Baker, M., dan Wurgler, J. (2004b). Appearing and Disappearing Dividends : The Link to Catering Incentives. Journal of Financial Economics, 73(2), 271-288.

Black, F. (1996). The Dividend Puzzle. The Journal of Portfolio Management, Special Issue, 8-12.

Black, F., dan Scholes, M. (1974). The Effects of Dividend Yield and Dividend Policy on Common Stock Prices and Returns. Journal of Financial Economics, 1(1), 1-22.

Easterbrook, F. H. (1984). Two Agency Cost Explanations of Dividends. The American Economic Review, 74(4), 650-659.

Gordon, M. J. (1959). Dividends, Earnings, and Stock Prices. The Review of Economics and Statistics, 41(2), 99-105.

Li, W., dan Lie, E. (2006). Dividend Changes and Catering Incentives. Journal of Financial Economics, 80(2), 293-308.

John, K., dan Williams, J. (1985). Dividends, Dilution, and Taxes: A Signalling Equilibrium. The Journal of Finance, 40(4), 1053-1070.

Miller, M. H., and Rock, K. (1985). Dividend Policy under Asymmetric Information. The Journal of Finance, 40(4), 1031-1051.

Shiller, R. J. (1981). Do Stock Prices Move Too Much to be Justified by Subsequent Changes in Dividends? American Economic Review, 71(3), 421-36.

Srinivasan. (2012). Determinants of Equity Share Prices in India: A Panel Data Approach, The Romanian Economic Journal, 15(46), 205-228.

Yoon, P. S., and Starks, L. T. (1995). Signaling, Investment Opportunities, and Dividend Announcements. Review of Financial Studies, 8(4), 995-1018.

Zakaria, Z., Muhammad, J. and Zulkifli, A. H. (2012). The Impact of Dividend Policy on The Share Price Volatility : Malaysian Construction and Material Companies. International Journal of Economics and Management Sciences, 2(5), 1-8.

Zaman, S. (2011). Is Dividend Policy An Important Determinant of Market Performance : Focus on Private Banks of Bangladesh. World Review of Business Research, 1(4), 135141. 